\title{
Oksidatif, Apoptotik ve İnflamatuar Sinyal Yolakları üzerinden C6 Glioblastoma Hücrelerindeki ML351'in Antiproliferatif Etkileri
}

\author{
Ceyhan HACIOĞLU ${ }^{1}{ }^{1}$, Fatih KAR in $^{2}$
}

\section{öz}

Amaç: Kanser tedavisindeki başarılı yaklaşımlardan biri de spesifik inhibitörlerin kullanılmasıdır. Çoklu doymamış yağ asitlerinin metabolizmasından sorumlu olan 12/15-lipoksijenaz (12/15-LOX) nöronlarda oksidatif stres kaynaklanan hücre ölümüne aracılık etmesinin yanı sıra, kanser gibi birçok önemli hastalıkta yer alan metabolitlerin üretemini de gerçekleştirir. Bu çalı̧̧mada, 12/15-LOX inhibitörü olan ML351'in C6 glioblastoma hücrelerin üzerindeki antiproliferatif etkilerini çeşitli biyokimyasal süreçler üzerinden araştırılması amaçlanmıștır.

Gereç ve Yöntemler: Çalışmada önce C6 hücreleri için sitotoksik ML351 konsantrasyonları metil tiazolil tetrazolyum (MTT) kullanılarak tespit edilmiştir ve ardından total oksidan kapasite (TOS), sitokrom c (CYC), kaspaz 3 (CASP3), tümör nekroz faktör alfa (TNF- $\alpha$ ) ve interlökin-6 (IL-6) seviyeleri ölçüldü.

Bulgular: Sonuç olarak, ML351 C6 hücreleri üzerinde konsantrasyon bağımlı anti-proliferatif etkilerinin olduğu görüldü. ML351 uygulamasının C6 hücrelerinde oksidatif strese neden olarak TOS seviyelerini artırdığı belirlendi. ML351 uygulanması kontrol grubu ile karşılaştıııldığında CASP3 ve CYC seviyelerini artırdı $(\mathrm{p}<0,001)$. Bu sonuçlara göre, ML351 uygulamasının C6 hücrelerinde apoptozu indüklediği görüldü. Öte yandan, ML351 ile tedavi edilen C6 hücrelerinde kontrol grubuna göre TNF- $\alpha$ ve IL-6 seviyelerinin düştüğ̈̈ belirlendi $(\mathrm{p}<0,01)$.

Sonuç: Çalışmamız, C6 glioma hücrelerinde ML 351 uygulamasının pro-oksidan/oksidan dengesini bozarak oksidatif hasar ve apoptoza neden olduğunu ve inflamasyonu azalttığını göstermektedir. Bu nedenle bir antikanser ilaç olma potansiyeline sahip ML351'in farklı kanser hücre hatlarındaki faklı metabolik yolaklar üzerindeki etkilerini araştıran daha ileri çalışmalar yapılmalıdır.

Anahtar Kelimeler: ML351; C6 glioblastoma; oksidatif stres; apoptoz; inflamasyon.

\section{Antiproliferative Effects of ML351 on C6 Glioblastoma Cells through Oxidative, Apoptotic and İnflammatory Signaling Pathways}

\begin{abstract}
Aim: One of the successful approaches in cancer treatment is the use of specific inhibitors. Responsible for the metabolism of polyunsaturated fatty acids, 12/15-lipoxygenase (12/15-LOX) not only mediates cell death caused by oxidative stress in neurons, but also produces metabolites involved in many important diseases such as cancer. In this study, it was aimed to investigate the anti-proliferative effects of ML351, 12/15-LOX inhibitor, on C6 glioblastoma cells through various biochemical processes.

Material and Methods: In the study, cytotoxic ML351 concentrations for C6 cells were determined using methyl thiazolyl tetrazolium (MTT), and then total oxidant capacity (TOS), cytochrome c (CYC), caspase 3 (CASP3), tumor necrosis factor alpha (TNF- $\alpha$ ) and interleukin-6 (IL-6) levels were measured.

Results: As a result, it was found to have concentration dependent anti-proliferative effects on ML351 C6 cells. It was determined that ML351 treatment increased TOS levels by causing oxidative stress in C6 cells. The ML351 treatment increased CASP 3 and CYC levels compared to the control group $(\mathrm{p}<0.01)$. Based on these results, it was observed that ML351 treatment induced apoptosis in C6 cells. On the other hand, TNF- $\alpha$ and IL-6 levels were decreased in C6 cells treated with ML351 compared to the control group ( $\mathrm{p}<0.01)$.

Conclusion: Our study shows that ML 351 treatment causes oxidative damage and apoptosis by disrupting the prooxidant/oxidant balance and decreases inflammation in C6 glioma cells. Therefore, further studies should be conducted to investigate the effects of ML351, which has the potential to be an anticancer drug, on different metabolic pathways in different cancer cell lines.
\end{abstract}

Keywords: ML351; C6 glioblastoma; oxidative stress; apoptosis; inflammation.

1 Düzce Üniversitesi Tıp Fakültesi Tıbbi Biyokimya Anabilim Dalı, Düzce, Türkiye

2 Kütahya Sağlık Bilimleri Üniversitesi Uygulama ve Araştırma Merkezi, Kütahya, Türkiye 


\section{Gíiș}

Gliomlar, glial hücrelerden kaynaklanan ve merkezi sinir sisteminin (MSS) en sık görülen tümörleridir (1). Malign glioma, sıklıkla yüksek oranda morbidite ve mortalite ile sonuçlanan birincil beyin tümörüdür (2). Gliomlar metastaz yapmaz, lokal olarak infiltre olur, komşu dokulara yayılır ve kötü prognoz gösterir (3). Ne yazık ki, son yıllarda, gliomalar için çeşitli moleküler yolaklar ve çeşitli terapötik hedefler önermiş olsa da, klinik deneylerde başarı sağlanamamıştır. Ancak moleküler ve genetik teknolojik gelişmeler ve hastalığın fizyolojik ve biyokimyasal mekanizmalarının anlaşılması sayesinde daha etkili bir tedavi ile hasta sağ kalımı ve yaşam kalitesi yüksek tutulabilir. Bu yüzden, glioma tümörleri için mevcut moleküler bilgiler arttıkça, yenilikçi tedavileri incelemek için uygun hayvan glioma modellerinin önemi de gün geçtikçe artmaktadır. Hayvan glioma modelleri, laboratuvar hayvanları için tümörojenik olan ve insan gliomalarının temel biyolojik özelliklerini simüle edebilen glioma hücre hatlarından üretilir. Nöro-onkolojide yaygın olarak kullanılan sıçan C6 hücre hatları, tümörogenez, invazyon, migrasyon ve anjiyogenez gibi glioma özelliklerini analiz etmek için yaygın bir şekilde kullanılmaktadır (4).

Çoklu doymamış yağ asitlerinin (ÇDYA) metabolizması hücre sinyallemesi, inflamasyon, metabolizma ve hücre proliferasyonu üzerindeki rolleri kapsamlı bir şekilde ortaya konmuştur (5). Bilinen biyolojik işlevlerine rağmen ÇDYA'lar, topluca oksipinler adı verilen lipitten türetilen moleküllerin sentezi için birer substrattırlar. Siklooksijenaz (COX), lipoksijenazlar (LOX) ve/veya sitokrom P450 enzimleri tarafindan metabolize edilen ÇDYA'lar, kanser dahil bir dizi fizyolojik ve patolojik süreçte sinyal görevi görebilen moleküller üretirler (6). Lipoksijenaz sinyal yolağı ile kanser arasındaki ilişki, siklooksijenaz yolundan daha az araştırılmıştır. LOX'ların ekspresyonu normalde düşüktür veya normal dokularda yoktur, ancak kanser gibi patolojik koşullar altında ekspresyonu artmaktadır. LOX'lar artmış ekspresyonu kolon, prostat, göğüs ve pankreas kanserlerinde tanımlanmıştır ve tümör hücresi proliferasyonu, göçü ve kötüleşen prognoz ile ilişkilendirilmiştir (7). LOX inhibitörleri esas olarak inflamatuar durumların tedavisinde ilgi çekmiştir. Giderek artan sayıda araştırma, LOX inhibitörlerinin kanserlerin kemoprevansiyonundaki rolünü desteklemektedir (8). ML351, inme ve nörodejeneratif bozuklukların patofizyolojisinde rol oynayan 12/15LOX'in in vitro olarak güçlü ve seçici inhibisyonu ve oksidatif stresle ilişkili nöronal hücre ölümünden koruması nedeniyle terapötik bir strateji olarak önerilmiştir (9).

$\mathrm{Bu}$ çalışmada 12/15 LOX inhibitörü olarak ML351 uygulamasının C6 glioma hücrelerindeki inflamatuar, oksidatif stresi ve apoptotik yolakları modüle ederek hücre proliferasyonu üzerindeki etkilerinin araştırılması hedeflendi. ML351'in bu sinyal yolakları üzerindeki etkilerini belirlemek için reaktif oksijen türleri (TOS), kaspaz 3 (CASP3) seviyeleri, sitokrom c (CYC), interlökin-6 (IL6) ve tümör nekroz faktör $\alpha$ (TNF $\alpha$ ) seviyeleri ölçüldü.

\section{GEREÇ VE YÖNTEMLER}

\section{Hücre kültürü ve ML315 uygulaması}

Amerikan Tipi Kültür Koleksiyonundan (ATCC, Rockville, MD, ABD) satın alınan C6 hücre hattının, $\% 10(\mathrm{~h} / \mathrm{h})$ fetal sığır serumu, $\% 1(\mathrm{~h} / \mathrm{h})$ penisilinstreptomisin (sırasıla $100 \mathrm{U} / \mathrm{ml}$ - $100 \mu \mathrm{g} / \mathrm{ml}$ ) içeren Dulbecco Modifiye Kartal Ortaminda (DMEM) kontrollü şartların $\left(37^{\circ} \mathrm{C}\right.$ 'de \%95 hava ve \% $\left.5 \mathrm{CO}_{2}\right)$ sağlandı̆̆ inkübatörde proliferasyonu sağlandı. Hücreler ilk önce 25 $\mathrm{cm}^{2}$ hücre kültürü şişelerinde birleşene kadar büyütüldü ve ardından $75 \mathrm{~cm}^{2}$ hücre kültürü şişelerine aktarıldı. Genel bir prosedür olarak, yeterli konfluansa (> \%80) ulaşan hücreler $\% 0,25$ tripsin-1 $\mathrm{mM}$ etilendiamintetraasetik asit (EDTA) çözeltisi ile hücre kültürü şişelerinden ayrılması sağlandı.

\section{Hücre canlılığının analizi}

C6 hücreleri (5×10 3 yoğunlukta) 96 kuyucuklu plakalarda yetiştirildi ve kültür ortamına yapışan hücreler 24 saat süreyle dimetil sülfoksit (DMSO) içerisinde çözdürülerek hazırlanan $1,2,4,8, \quad 16,32$ ve $64 \quad \mu \mathrm{M}$ konsantrasyonlarındaki ML3151 ile inkübe edildiler. İşlemden sonra, her çukura 3 saat süreyle $0,5 \mathrm{mg} / \mathrm{ml}$ metil tiazolil tetrazolyum (MTT) ilave edildi. Üç saat sonra, formazan tuzları DMSO ile çözündürüldü ve ölçümler 570 nm'de mikroplaka okuyucusu ile yapıldı. ML351 uygulaması yapılmayan kontrol grubu hücrelerin canlılığ1 $\% 100$ olarak kabul edilmiş ve deney gruplarındaki hücrelerin canlılığı bu kontrol hücrelerine göre hesaplanmıştır. C6 hücrelerinin canlılık yüzdesi aşağıdaki formül kullanılarak belirlendi:

(ML351 uygulanmış hücrelerin optik yoğunluğu - Körün optik yoğunluğu) / (Kontrol grubunun optik yoğunluğu Körün optik yoğunluğu) $\times 100$

MTT analiz sonuçlarına göre diğer biyokimyasal analizlerde kullanılmak üzere 3 farklı ML351 konsantrasyonu belirlendi: (1) 2,7 $\mu \mathrm{M}$ ML351 konsantrasyonu (hücre canlılığında anlamlı bir düşüşün olduğu ilk konsantrasyon), (2) $6,1 \quad \mu \mathrm{M} \quad$ ML351 konsantrasyonu (hücre canlılığın $\% 50$ düştüğü konsantrasyon=IC50) ve (3) $4,2 \mu \mathrm{M} \quad$ ML351 konsantrasyonu (bir ara konsantrasyonu olarak).

\section{Hücre lizatı hazırlama ve biyokimyasal analiz}

ML351 konsantrasyonları ile 24 saat süreyle inkübe edilen C6 hücrelerindeki TOS, CASP3, CYC, IL6 ve $\mathrm{TNF} \alpha$ seviyelerini belirlemek için hücre lizatları, önceki çalışmamızda bahsedildiği gibi hazırlanmıştır (10). Protein seviyeleri Lowry yöntemiyle ölçüldü (11). Hazırlanan hücre lizatları, biyokimyasal analizler için hemen kullanıldı.

2,7, 4,2 ve 6,1 $\mu \mathrm{M}$ ML351 konsantrasyonları ile inkübe edilen C6 hücrelerindeki TOS seviyeleri ticari olarak mevcut kit (Rel Assay Diagnostics) kullanılarak üretici firma talimatları doğrultusunda analiz edilmiştir. Hücrelerdeki toplam TOS miktarını temsil eden renk yoğunluğu, $530 \mathrm{~nm}$ 'de spektrofotometrik olarak ölçüldü. Sonuçlar $\mu \mathrm{mol} \mathrm{H}_{2} \mathrm{O}_{2}$ Equiv./L olarak ifade edildi.

CYC ve CASP3 seviyeleri apoptotik belirteçler olarak uygun ticari kitler kullanılarak hücre lizatlarında ölçülmüştür (sırasıyla Kat no. SEA594Ra ve SEA626Ra; Cloud Clone Corporation). CASP3 ve CYCS için enzimsubstrat reaksiyonları $450 \mathrm{~nm}$ 'de spektrofotometrik olarak belirlendi. CASP3 ve CYCS seviyeleri ng/mg protein olarak ifade edildi. 
İnflamtuar biyobelirteçler olarak IL6 ve TNF $\alpha$ seviyeleri ticari olarak mevcut kitler (sırasıyla Kat no. SEA079Ra ve SEA133Ra; Cloud Clone Corporation) kullanılarak üretici firma talimatları doğrultusunda mikroplaka okuyucu yardımıyla ölçülmüştür. TNF $\alpha$ ve IL6 seviyeleri $\mathrm{pg} / \mathrm{mg}$ protein olarak ifade edildi.

\section{Ístatiksel analiz}

Deneysel veriler Shapiro-Wilk normallik testi ile normal dağılıma uyup uymadığı kontrol edilmiştir. Normal olarak dağıtılan veriler tek yönlü ANOVA ile analiz edildi ve Tukey'in post-doc testi olarak kullanıldı. Veriler ortalama \pm standart sapma olarak verildi. İstatistiksel anlamlılık $\mathrm{p}<0,05$ olarak kabul edildi.

\section{BULGULAR}

Farklı ML351 konsantrasyonlarının C6 hücre canlılığı üzerindeki etkileri Şekil 1'de gösterilmiştir. C6 hücreleri, ML351 uygulamasının ardından konsantrasyona bağlı bir azalma göstermiştir. Özellikle, $16 \mu \mathrm{M}$ ML351 üzerindeki konsantrasyonlarda herhangi bir hücre canlılı̆̆ tespit edemedik. Bununla birlikte, 24 saatlik MTT sonuçlarına göre, 6,1 $\mu \mathrm{M}$ ML351 uygulanması kontrol grubuna göre hücre canlılığında yaklaşık \% 53,8'lik bir düşüş göstermiştir $(p<0,01)$. Ayrıca, 24 saat boyunca 2,7 ve 4,2 $\mu \mathrm{M}$ ML351 konsantrasyonları ile inkübe edilen hücrelerin canlılığında, kontrol grubuna kıyasla \%15,2 ve \%29,4'lük bir azalma ile sonuçlandı $(\mathrm{p}<0,01)$.

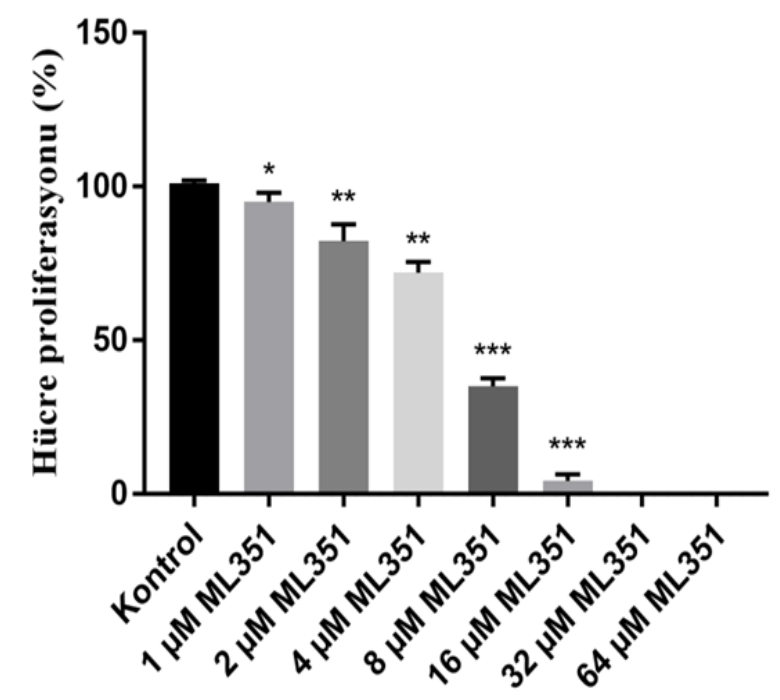

Şekil 1. ML351 uygulanan C6 glioblastoma hücrelerindeki MTT test sonuçları. * $\mathrm{p}<0,05$; ** $\mathrm{p}<0,01$; *** $\quad \mathrm{p}<0,001$ kontrol ile karşılaştırıldığında C6 hücrelerindeki TOS seviyeleri, artan ML351 konsantrasyonu ile artmıştır (Şekil 2). Kontrol seviyeleri ile karşılaştırıldığında, TOS seviyeleri 2,7, 4,2 ve $6,1 \mu \mathrm{M}$ ML351 konsantrasyonlarında sirasiyla \%17,3, \%30,5 ve $\% 58,1$ oranında artışı olduğunu bulduk $(\mathrm{p}<0,01)$. En düşük ortalama TOS seviyesi kontrol grubunda 4,6 $\mu \mathrm{mol}$ $\mathrm{H}_{2} \mathrm{O}_{2}$ Equiv./L ve en yüksek ortalama değer $6,1 \mu \mathrm{M}$ ML351 grubunda 7,36 $\mathrm{H}_{2} \mathrm{O}_{2}$ Equiv./L olmuştur.

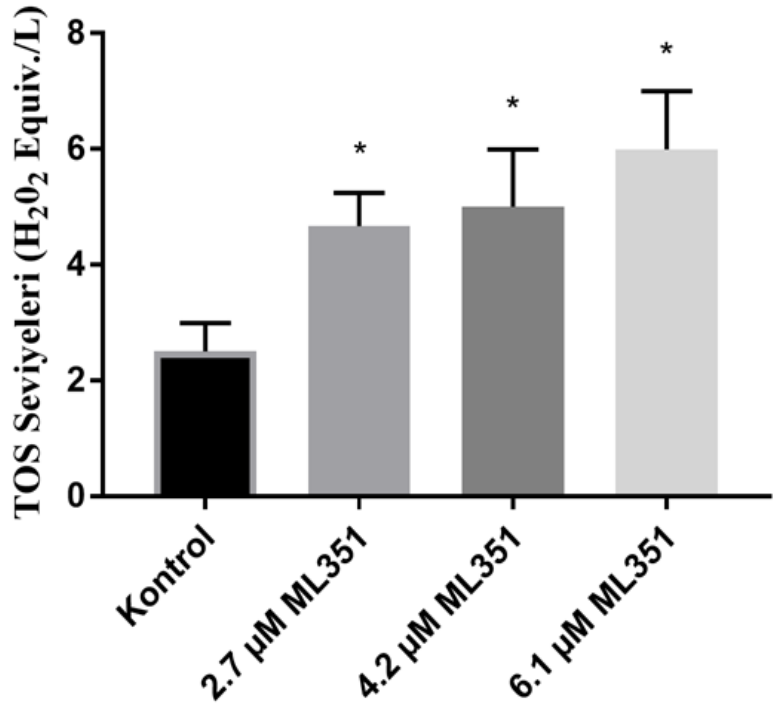

Şekil 2. ML351 konsantrasyonları uygulanan C6 glioblastoma hücrelerinde TOS seviyeleri. TOS: Toplam oksidan kapasite; ${ }^{*} \mathrm{p}<0,01$ kontrol ile karşılaştırıldığında

ML351 hücre içi apoptotik yolları etkileyen CASP3 ve CYC seviyelerinde değişikliğe neden olmuştur. Artan ML351 konsantrasyonlarının C6 hücrelerindeki apoptotik belirteçler üzerindeki etkileri Şekil 3A ve 3B'de gösterilmiştir. 24 saat $2,7,4,2$ ve $6,1 \mu \mathrm{M}$ ML351 konsantrasyonları ile inkübe edilen C6 hücreleri, kontrol grubuna kıyasla CASP3 seviyelerinde sirasıyla \%21,5, \% 38,3 ve $\% 68,1^{\prime}$ lik istatistiksel olarak anlamlı bir artış gösterdi ( $<<0,01$; Şekil 3A). Ayrıca, 2,7, 4,2 ve $6,1 \mu \mathrm{M}$ ML351 konsantrasyonları ile tedavi edilen C6 glioma hücrelerinde kontrol grubuna göre CYC seviyelerinde sirasıyla $\% 18,6, \% 25,9$ ve $\% 50,3$ 'lük düşüşler gözlenmiştir ( $<<0,01$; Şekil 3B).

Artan ML351 konsantrasyonlarına göre C6 hücrelerindeki inflamatuar sitokin seviyeleri, Şekil 4A ve 4B'de gösterilmiştir. Kontrol ile karşılaştırıldığında, 24 saat 2,7, 4,2 ve 6,1 $\mu \mathrm{M}$ ML351 konsantrasyonlarının uygulandığ1 gruplardaki TNF $\alpha$ seviyeleri sırasıyla \%33,7, \% 41,5 ve \%62,9'luk bir düşüş gösterdi $(\mathrm{p}<0,01$; Şekil 4A). Benzer şekilde, ML351 konsantrasyonlarının uygulandığı gruplardaki IL6 seviyeleri sırasıyla \%19,5, \% 32,7 ve \%46,2'lik bir düşüş gösterdi ( $<<0,01$; Şekil 4B). 

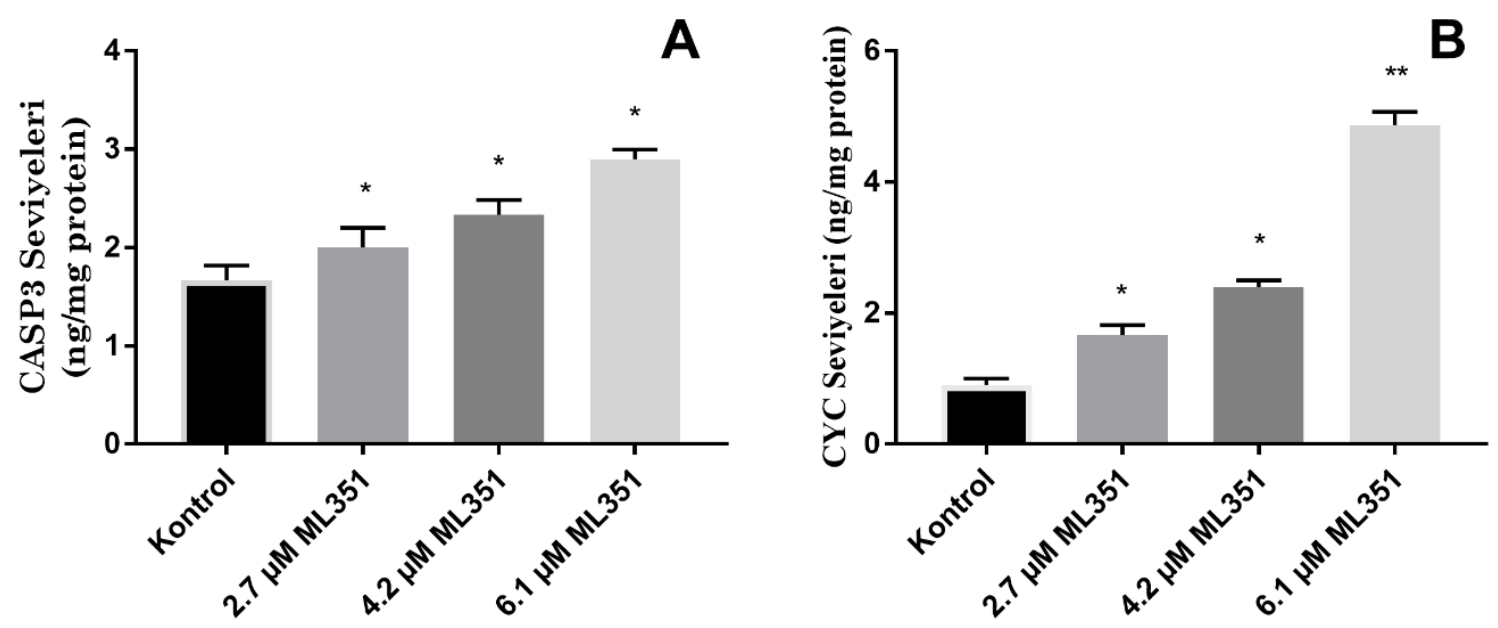

Şekil 3. ML351 konsantrasyonları uygulanan C6 glioblastoma hücrelerindeki apoptotik biyobelirteçler. A: CAPS3 seviyeleri; B: CYC seviyeleri; CASP3: Kaspaz 3; CYC: Sitokrom c; * p<0,01; ** p<0,001 kontrol ile karşılaştırıldığında
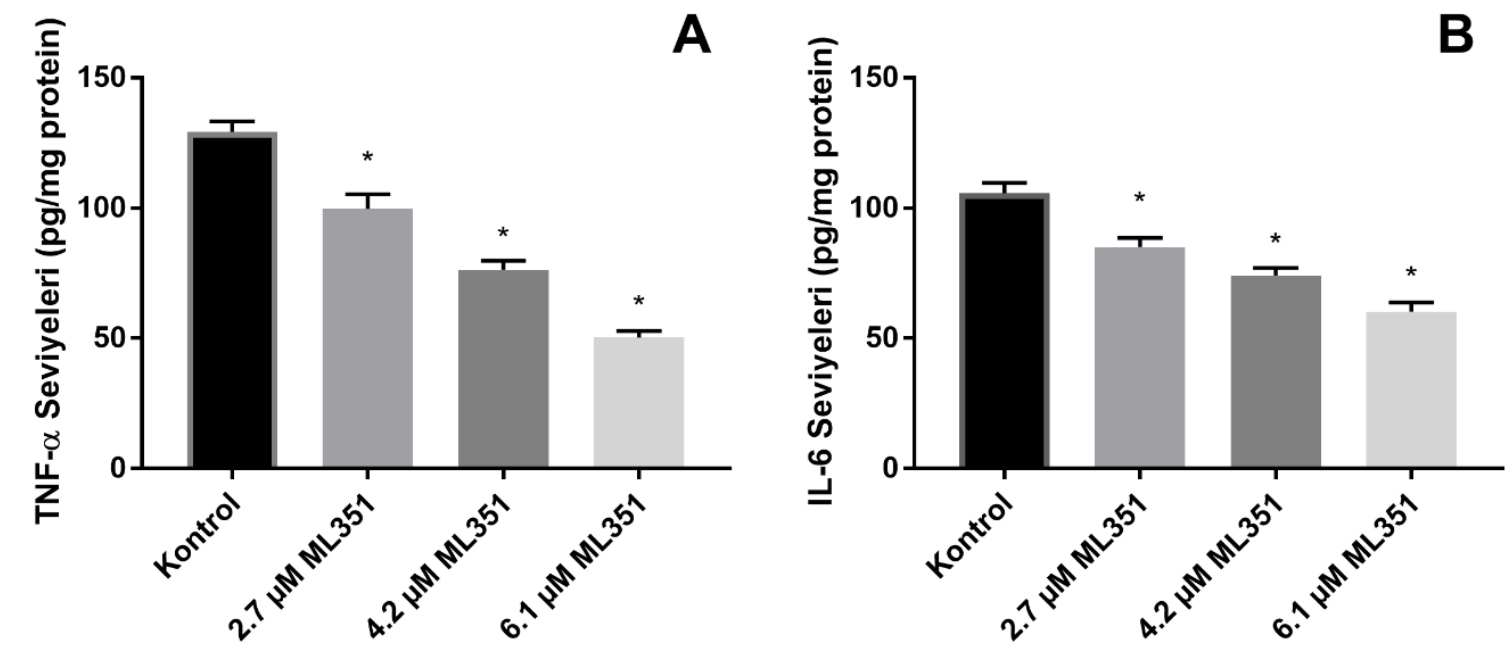

Şekil 4. ML351 konsantrasyonları uygulanan C6 glioblastoma hücrelerindeki inflamatuar biyobelirteçler. A: TNF- $\alpha$ seviyeleri; B: IL-6 seviyeleri; TNF- $\alpha$ : Tümör nekroz faktör alfa; IL-6: İnterlökin-6; * p<0,01 kontrol ile karşılaştırıldığında

\section{TARTISMA}

Çalışmamızda, farklı sürelerde konsantrasyonlarda (0-64 $\mu \mathrm{M})$ ML351 uygulamasının çeşitli biyokimyasal mekanizmaları tetikleyerek C6 glioma hücrelerinde antiproliferatif etkilere neden olup olmayacağının araştırılması amaçlandı. C6 hücreleri için belirlenen üç sitotoksik konsantrasyonun $(2,7,4,2$ ve $6,1 \mu \mathrm{M})$ oksidatif, apoptotik ve inflamatuar mekanizmaları üzerindeki etkileri analiz edildi. İlginç bir şekilde, ML351 uygulamasının C6 hücrelerinde TOS, CASP3 ve CYC seviyelerini artırırken, TNF $\alpha$ ve IL6 seviyelerini düşürerek hücre çoğalmasını baskıladığı bulundu.

Son yıllarda, kanser gelişiminde LOX'ların ve COX'ların aktivitesi dikkat çeken konular arasında yer almaktadır. ÇDYA'ların LOX ve COX aktivitesi ile oluşan oksipinler, hücre proliferasyonu, hücre adezyonu, migrasyon, anjiyogenez ve vasküler geçirgenlik gibi kanserogenez ile yakından ilişkili süreçlerin düzenlenmesinde rol oynamaktadırlar (12). LOX'un kanser gelişimi ve ilerlemesindeki rolü, insan tümör biyopsileri ve deneysel olarak indüklenmiş hayvan tümör modelleri üzerinde yapılan çalışmalarla ortaya konmuştur $(13,14)$. LOX'lar genellikle pro-inflamatuar uyaranlarla indüklenebilir ve çoğunlukla kolon, yemek borusu, akciğer prostatı ve göğüs kanseri dahil çeşitli epitelyal kanserlerde yapısal olarak ekspresyonun arttı̆̆ bildirilmiştir (15). Hücre çoğalmasını ve hücre ölümünü kontrol eden mekanizmalar arasındaki dengesizlik, kanserin ayırt edici özelliklerinden biridir (16). LOX aktivitesi ve bununla bağlantılı olarak oluşan LOX türevi ürünlerinin hücre proliferasyonu ve apoptoz arasındaki sinyalizasyon kaskatları etkileyerek tümör hücresi büyümesinin uyarılmasında rol oynayabilmektedir (17). LOX inhibitörleri esas olarak inflamatuar durumların tedavisinde ilgi çekse de, giderek artan sayıda araştırma, 
LOX inhibitörlerinin kanserlerin kemoprevansiyonundaki rolünü desteklemektedir (18). Hosseinymehr ve ark. (19), 15-LOX-1 inhibitörü olan kumarin türevlerinin PC3 ve DU145 prostat kanseri hücre hatlarında apoptozu indükleyerek anti-proliferatif etkiler gösterdiği rapor edilmiştir. Dahası, Jun ve ark. (20), PANC-1 pankreatik kanser hücre hatlarında bir dizi kumarin türevlerinin 24 saatlik inkübasyonu sonrasında antiproliferatif aktiviteler gösterdiğini bulmuşlardır. Bunlar arasında, 6farnesiloxikumarinin $4 \mu \mathrm{M}^{\prime}$ lık IC50 konsantrasyonu ile en güçlü antikanser etkiler sergilediği gösterilmiştir. Ayrica, LOX inhibitörlerinin in vitro sitotoksisite potansiyelini değerlendirmek için SKNMC (nöroblastoma), PC3 (prostat karsinomu) ve HT29 (kolorektal kanser) dahil olmak üzere üç farklı kanser hücresi hattında yüksek antikanser aktiviteler gösterdiği bildirilmiştir. Bizde bu çalışmada, ilk kez 12/15 LOX inhibitörü olarak ML351 uygulamasının C6 glioblastoma hücrelerinde oksidatif, apoptotik ve inflamtuar yolaklar üzerindeki etkisini ortaya çıkarmayı amaçladık. Biyokimyasal yol analizinden önce, MTT testi ile 2,7, 4,2 ve $6,1 \mu \mathrm{M}$ ML351'in etkili konsantrasyonları olduğu bulundu. C6 glioblastoma hücreleri için ML351 IC50 değerimiz 6,1 $\mu$ M'idi. Yukarıda bahsi geçen çalışmalarda kullanılan LOX inhibitörlerine göre nispeten daha yüksek IC50 değerimiz, glioblastoma hücrelerinin pankreatik kanser, prostat kanser, kolorektal kanser, nöroblastoma hücrelerine göre LOX inhibitörlerine daha dirençli olmasından kaynaklanıyor olabilir. Öte yandan, bahsi geçen çalışmalardaki kullanılan LOX inhibitörlerinin yapısal olarak ML351'den farklı olması da, çalışmamızdaki IC50 değerindeki farklılığ açıklayabilir.

Oksidatif stres, oksidanlar veya reaktif oksijen türleri (ROS) olarak adlandırılan serbest radikallerin ve reaktif metabolitlerin üretimi ve bunların antioksidanlar olarak adlandirılan koruyucu mekanizmalarla ortadan kaldırılması arasındaki bir dengesizlik olarak tanımlanır (21). Tümör hücrelerinin temel özelliklerinden biri, normal hücrelere kıyasla daha fazla hayatta kalma yetenekleridir. ROS'un, hücre proliferasyonunu, hayatta kalmasını ve hücresel göçü artırma yetenekleri nedeniyle tümörijenik olduğu bildirilmektedir. ROS, DNA hasarına neden olarak tümör oluşumunu ve ardından tümör ilerlemesini başlatan genetik lezyonlara yol açabilir (22). Öte yandan ROS, hücresel yaşlanmayı ve hücre ölümünü de indükleyebilir ve bu nedenle anti-tümorijenik ajanlar olarak işlev görebilir. ROS'un tümör hücresi hayatta kalmasını teşvik edip etmediği veya anti-tümorijenik ajanlar olarak hareket edip etmediği hücre ve dokulara, ROS üretiminin konumuna ve bireysel ROS konsantrasyonuna bağlıdır (23). Chang ve ark. (24) yapmış olduğu çalışmada, LOX inhibitörlerinin kolorektal kanser hücrelerinde istilayı, proliferasyonu ve ROS üretimini baskıladığını bildirmişlerdir. Aksine, çalışmamızda, ML351 uygulamasını takiben C6 glioblastoma hücrelerindeki TOS seviyelerinde artış olduğunu tespit ettik. TOS içeriğindeki artış, bize ML315 uygulamasından sonra oksidatif stresteki artışı gösterir. $\mathrm{Bu}$ nedenle, farklı kanser türlerindeki farklı LOX inhibitörlerinin farklı etkiler gösterdiğini söyleyebiliriz. Çalışmamızdaki ROS seviyelerinde keskin artış, C6 glioblastoma hücrelerinin homeostazını bozmanın ve onları apoptoza girmeye zorlamanın bir yolu da ML351 uygulaması olabilir.

Apoptozun veya programlanmış hücre ölümünün indüklenmesi, çoğu kemoterapötik ajanın arzu edilen bir özelliğidir (25). Apoptotik yol, CYC'nin mitokondriden sitozole salınmasını ve kaspaz-9'un aktivasyonunu içerir. Kaspaz-8 veya kaspaz-9 aktive edildiğinde, kaspaz-3, -6 ve -7 gibi efektör kaspazlarının aktivasyonunu içeren ortak bir yolu indükleyerek kaspaz kaskatını harekete geçirir (26). Çeşitli çalışmalar, LOX aktivasyonunun bloke edilmesinin farklı insan kanserlerinde apoptozu indükleyebileceğini göstermiştir. Avis ve ark. (27), LOX inhibitörlerinin, MCF-7 insan meme kanseri hücrelerinde anti-apoptotik protein olan Bcl-2 ekspresyonunu azaltarak ve pro-apoptotik protein olan bax ekspresyonunu arttırarak apoptozu indüklediğini göstermişlerdir. Benzer şekilde, bir başka çalışmada, insan akciğer kanseri büyümesinde rol oynayan 5-LOX yolunun inhibisyonu, in vitro olarak çeşitli akciğer kanseri hücrelerinde proliferasyonunu baskıladığı ve apoptozu indüklediği rapor edilmiştir (28). Wong ve ark. (29), AGS ve MKN28 mide kanseri hücre hatlarında LOX inhibitörü uygulamasının, apoptozun azalmış Bcl-2 seviyeleri ve kaspaz-7 aktivasyonuyla indüklendiğini gösterdi. Ek olarak, MK591 uygulamasının LNCaP prostat kanser hücrelerinde hem protein kinaz C-epsilon hem de 5-LOX inhibe ederek apoptozu indüklediği bulunmuştur (30). Literatürdeki bu bilgiler, kanser hücrelerindeki LOX inhibitörlerinin neden olduğu apoptozun önemini ortaya koymaktadır. Bu çalışmada, özellikle oksidatif stres üzerinden apoptozu indükleyen ML351'in antikanser aktivitelerini gösterdik. C6 glioma hücrelerinde ML351 uygulamasının, CASP3 ve CYC seviyelerini arttırarak apoptozu desteklediğini bulduk. Bu sonuçlar, gliomaların tedavisinde anti-kanser ilaç direnci için umut verici olabilir.

İnflamasyonun tümör ilerlemesinde önemli bir rolü oynadığı ve kanserin ayırt edici özelliklerinden biri olduğu kabul edilmektedir (31). Nöroinflamasyon yolağındaki glial-nöronal hücre etkileşimlerinde önemli bir rol oynayan moleküller pro- inflamatuar sitokinlerdir (32). Bu sitokinlerden TNF $\alpha$ ve IL6, glia ve nöronlar gibi farklı hücre tiplerinde eksprese edilir ve örneğin inflamasyon, oksidatif stres ve apoptoz gibi hücre sinyal yolaklarını tetikleyebilir (33). 5-LOX, pro-inflamatuar uyaranlarla indüklenebilir ve akciğer, prostat, meme ve kolon dahil epitel kanserlerinde eksprese edilir (34). Bu nedenle, 5-LOX inhibitörleri, kemopreventif etkileri nedeniyle hedeflenmiştir. 5-LOX aktivitesinin inhibisyonunun prostat kanseri hücre proliferasyonunu ve ayrıca karsinojenin indüklediği akciğer tümör oluşumunu bloke ettiği gösterilmiştir (35). Bu çalışma, ML351 uygulamasının C6 glioblastoma hücrelerinin de yukarıda bahsi geçen çalışmalarda olduğu gibi davranabileceğini göstermektedir. ML351 uygulamas1 C6 hücrelerinde benzer şekilde pro- inflamatuar sitokin sentezinin artmasına neden oldu. ML351 ile indüklenen C6 hücrelerinin TNF $\alpha$ ve IL6 seviyelerinin, sonunda glioblastoma hücre ölümüne neden olan apoptotik etkilere neden olabileceğini düşünüyoruz.

\section{SONUC}


Sonuç olarak, mevcut sonuçlar, LOX inhibitörü olan ML351'in, C6 glioblastoma hücrelerinde proliferasyonun inhibisyonu ve apoptoz indüksiyonu üzerindeki etkisini göstermiştir. Ayrıca ML351 CYC salınımı, CASP3 aktivasyonu yoluyla apoptozu indüklediğini de gösterdik. LOX inhibitörü tedavisi ayrıca pro-inflamatuar sitokin (TNF $\alpha$ ve IL6) seviyelerini düşürdü. LOX yolaklarının bloke edilmesi, glioblastoma tedavisinde umut vaat etmesi nedeniyle, moleküler temelli daha ileri araştırmalara ihtiyaç vardır.

Yazarların Katkıları: Fikir/Kavram: C.H., F.K.; Tasarım: C.H., F.K.; Veri Toplama ve/veya İşleme C.H., F.K.; Analiz ve/veya Yorum: C.H., F.K.; Literatür Taraması: C.H., F.K.; Makale Yazımı: C.H.; Eleştirel İnceleme: C.H., F.K.

\section{KAYNAKLAR}

1. Modrek AS, Bayin NS, Placantonakis DG. Brain stem cells as the cell of origin in glioma. World $\mathbf{J}$ Stem Cells. 2014; 6(1): 43-52.

2. Louis DN, Ohgaki H, Wiestler OD, Cavenee WK, Burger PC, Jouvet A, et al. The 2007 WHO classification of tumours of the central nervous system. Acta Neuropathol. 2007; 114(2): 97-109.

3. Chen R, Smith-Cohn M, Cohen AL, Colman H. Glioma subclassifications and their clinical significance. Neurotherapeutics. 2017;14(2): 284-97.

4. Grobben B, De Deyn PP, Slegers H. Rat C6 glioma as experimental model system for the study of glioblastoma growth and invasion. Cell Tissue Res. 2002; 310(3): 257-70.

5. Colquhoun A. Cell biology-metabolic crosstalk in glioma. Int J Biochem Cell Biol. 2017; 89: 171-81.

6. Azrad M, Turgeon C, Demark-Wahnefried W. Current evidence linking polyunsaturated Fatty acids with cancer risk and progression. Front Oncol. 2013; 3: 224.

7. Souza FDC, Ferreira MT, Colquhoun A. Influence of Lipoxygenase Inhibition on Glioblastoma Cell Biology. Int J Mol Sci. 2020; 21(21): 8395.

8. Orafaie A, Matin MM, Sadeghian H. The importance of 15-lipoxygenase inhibitors in cancer treatment. Cancer Metastasis Rev. 2018 Sep;37(2-3):397-408.

9. Rai G, Joshi N, Perry S, Yasgar A, Schultz L, Jung JE, et al. Discovery of ML351, a potent and selective inhibitor of human 15-lipoxygenase-1. Available from http://www.ncbi.nlm.nih.gov/books/NBK190602

10. Hacioglu C, Kar F, Kacar S, Sahinturk V, Kanbak G. Bexarotene inhibits cell proliferation by inducing oxidative stress, DNA damage and apoptosis via PPAR $\gamma / \mathrm{NF}-\kappa \mathrm{B}$ signaling pathway in C6 glioma cells. Med Oncol. 2021; 38(3): 31.

11. Lowry OH, Rosebrough NJ, Farr AL, Randall RJ. Protein measurement with the Folin phenol reagent. J Biol Chem. 1951; 193: 265-275.

12. Hanahan D, Weinberg RA. Hallmarks of cancer: the next generation. Cell. 2011; 144(5): 646-74.

13. Catalano A, Procopio A. New aspects on the role of lipoxygenases in cancer progression. Histol Histopathol. 2005; 20(3): 969-75.

14. Tang DG, Bhatia B, Tang S, Schneider-Broussard R. 15-lipoxygenase 2 (15-LOX2) is a functional tumor suppressor that regulates human prostate epithelial cell differentiation, senescence, and growth (size). Prostaglandins Other Lipid Mediat. 2007; 82(1-4): $135-46$.

15. Pidgeon GP, Lysaght J, Krishnamoorthy S, Reynolds JV, O'Byrne K, Nie D, et al. Lipoxygenase metabolism: roles in tumor progression and survival. Cancer Metastasis Rev. 2007; 26(3-4): 503-24.

16. DeBerardinis RJ, Chandel NS. Fundamentals of cancer metabolism. Sci Adv. 2016; 2(5): e1600200.

17. Schneider C, Pozzi A. Cyclooxygenases and lipoxygenases in cancer. Cancer Metastasis Rev. 2011; 30(3-4): 277-94.

18. Hyde CA, Missailidis S. Inhibition of arachidonic acid metabolism and its implication on cell proliferation and tumour-angiogenesis. Int Immunopharmacol. 2009; 9(6): 701-15.

19. Hosseinymehr M, Matin MM, Sadeghian H, Bahrami AR, Kaseb-Mojaver N. 8-Farnesyloxycoumarin induces apoptosis in PC-3 prostate cancer cells by inhibition of 15-lipoxygenase-1 enzymatic activity. Anticancer Drugs. 2016; 27(9): 854-62.

20. Jun M, Bacay AF, Moyer J, Webb A, Carrico-Moniz D. Synthesis and biological evaluation of isoprenylated coumarins as potential anti-pancreatic cancer agents. Bioorg Med Chem Lett. 2014; 24(19): 4654-58.

21. Durackova Z. Some current insights into oxidative stress. Physiol Res. 2010; 59(4): 459-69.

22. Azad MB, Chen Y, Gibson SB. Regulation of autophagy by reactive oxygen species (ROS): implications for cancer progression and treatment. Antioxid Redox Signal. 2009; 11(4): 777-90.

23. Reuter S, Gupta SC, Chaturvedi MM, Aggarwal BB. Oxidative stress, inflammation, and cancer: how are they linked? Free Radic Biol Med. 2010; 49(11): 1603-16.

24. Chang J, Tang N, Fang Q, Zhu K, Liu L, Xiong X, et al. Inhibition of COX-2 and 5-LOX regulates the progression of colorectal cancer by promoting PTEN and suppressing PI3K/AKT pathway. Biochem Biophys Res Commun. 2019; 517(1): 1-7.

25. Pistritto G, Trisciuoglio D, Ceci C, Garufi A, D'Orazi G. Apoptosis as anticancer mechanism: function and dysfunction of its modulators and targeted therapeutic strategies. Aging (Albany NY). 2016; 8(4): 603-19.

26. Jeong SY, Seol DW. The role of mitochondria in apoptosis. BMB Rep. 2008; 41(1): 11-22.

27. Avis I, Hong SH, Martinez A, Moody T, Choi YH, Trepel J, et al. Five-lipoxygenase inhibitors can mediate apoptosis in human breast cancer cell lines through complex eicosanoid interactions. FASEB J. 2001; 15(11): 2007-9.

28. Avis IM, Jett M, Boyle T, Vos MD, Moody T, Treston AM, et al. Growth control of lung cancer by interruption of 5-lipoxygenase-mediated growth factor signaling. J Clin Invest. 1996; 97(3): 806-13.

29. Wong BC, Wang WP, Cho CH, Fan XM, Lin MC, Kung HF, et al. 12-Lipoxygenase inhibition induced apoptosis in human gastric cancer cells. Carcinogenesis. 2001; 22(9): 1349-54.

30. Sarveswaran S, Thamilselvan V, Brodie C, Ghosh J. Inhibition of 5-lipoxygenase triggers apoptosis in 
prostate cancer cells via down-regulation of protein kinase C-epsilon. Biochim Biophys Acta. 2011; 1813(12): 2108-17.

31. Mantovani A. Cancer: Inflaming metastasis. Nature. 2009; 457(7225): 36-7.

32. Rauert H, Stühmer T, Bargou R, Wajant H, Siegmund D. TNFR1 and TNFR2 regulate the extrinsic apoptotic pathway in myeloma cells by multiple mechanisms. Cell Death Dis. 2011; 2(8): e194.

33. Martin M, Wei H, Lu T. Targeting microenvironment in cancer therapeutics. Oncotarget. 2016; 7(32): 52575-83.

34. Pidgeon GP, Lysaght J, Krishnamoorthy S, Reynolds JV, O'Byrne K, Nie D, Honn KV. Lipoxygenase metabolism: roles in tumor progression and survival. Cancer Metastasis Rev. 2007; 26(3-4): 503-24.

35. Gunning WT, Kramer PM, Steele VE, Pereira MA. Chemoprevention by lipoxygenase and leukotriene pathway inhibitors of vinyl carbamate-induced lung tumors in mice. Cancer Res. 2002; 62(15): 4199-201. 